present National Central Library and the National Lending Library for Science and Technology, and its ultimate location might be either wholly at Boston Spa or split between Boston Spa and somewhere else.

The National Libraries of Scotland and Wales and the university libraries at Oxford and Cambridge are outside the Dainton Committee's terms of reference, but the association considers that they should be brought into relationship with the National Library Service so that cooperation in the organizing of a nation-wide lending service and in the building up of collections might be studied.

A unified administration is essential for the efficiency of a large organization like the National Library Service. In this connexion the association recommends that the service should be the direct responsibility of the Government and should be administered as part of the Department of Education and Science. Within the present DES, responsibility for library matters appears to be shared between seven branches. The association suggests, therefore, that there should be a libraries branch of the department which would absorb the library and information responsibility of the other branches, and be responsible for bringing the National Library Service into being, and which would accept a new responsibility for coordinating the country's library service and information in all its divisions (without detriment to the responsibilities of the various library authorities). A Library Services Council should be established, the association says, to advise the Secretary of State on the discharge of all the functions entrusted to this branch.

\section{Journal Abbreviations}

THE somewhat confused situation over the abbreviation of scientific journals is brought out in the foreword to a new list of Abbreviated Titles of Biological Journals compiled on behalf of the Biological Council by $\mathrm{Mr}$ P. C. Williams (3rd edition, 1968; obtainable from the Institute of Biology, London, at 12s. 6d. post free (US $\$ 1 \cdot 75)$ ). This is a list of about 1,420 biological journals with their abbreviations selected with permission from the World List of Scientific Periodicals 1900-1960 (4th edition), with indications of the abbreviations recommended by the US Standards Institute where these differ.

To obtain the list, the quoted references in forty-five British biological journals were analysed. The journals were those published by societies affiliated to the Biological Council or, where the societies did not publish a journal, journals in that field of biology. The editors of these journals were asked in 1964 to analyse 1,000 consecutive quoted references according to the journals eited.

Originally it was intended to base this new edition entirely on the World List. When all was ready for press, however, the International Union of Biochemistry recommended that all journals in this field should adopt an American system of abbreviation and the Biochemical Journal proposed to act on this recommendation. The Biological Council decided then to include the American abbreviations in the list. From Mr Williams's account it seems, however, that not all was plain sailing.

In 1963 the US Standards Association had issued a code with a list of some 2,400 words with their abbrevia- tions. This list, published annually in the November issue of Biological Abstracts, was used to prepare the first amended draft of the Biological Council's booklet. Then Biological Abstracts and Chemical Abstracts agreed to adopt the same standard for abbreviating the journals they abstracted (this, writes Mr Williams, was the move that prompted the biochemists to recommend the adopting of the American abbreviations). For this purpose, the US Standards Institute, as it was now named, had prepared a new list which not only increased the number of words listed to about 5,200, but had altered many of the abbreviations in the earlier list. The alterations in many cases brought the system more into line with the World List system. A second draft of the Biological Council's list was prepared, based on the World List as before, but with alternative forms of abbreviations based on the new American list. Further complications arose because the 4th edition of the World List was the last in that format. Now annual supplements of new journal titles published since 1960, with their abbreviations, are being published based on the quarterly publication British Union Catalogue of Periodicals (BUCOP). The abbreviations in the supplements unfortunately differ in some respects from those in the 4th edition of the World List. Further muddle seems to have been caused by the British Standards Institution, which published its own standard for abbreviations in 1967 (BS 4148). This does not agree with the World List supplements and it recommends minor changes in the basic World List scheme. $\mathrm{Mr}$ Williams did not take into account the British Standard in compiling his list, for reasons he explains.

The choice therefore seems to lie between the British World List of journal titles and their abbreviations and the American list of words and their abbreviations. The differences between the two are not too great. The principal difference is that the American system is styled for computers. The British abbreviations could lead to less confusion, but the American system has the advantage that it is run by a full-time organization, the National Clearing House for Periodical Title Word Abbreviations, which can supply abbreviations of up to 100 words not in their list within 24 hours. The organization also brings out a quarterly supplement of additional words and their abbreviations.

The International Standards Organization (ISO) is continuing to produce an international standard. A universally agreed system would be nice, but as $\mathbf{M r}$ Williams says, "Once the two largest abstracting services outside Russia have put all their material into computer stores in one form, the chances of their changing are almost non-existent".

\section{Controlling Hovercraft}

THE way hovercraft have been developed in Britain has not always commanded instant applause. The National Research Development Corporation has adopted a canny policy of issuing only a limited number of licences in an attempt to minimize duplication of effort. Until recently, it also ran the research side of the business, through a subsidiary company called Hovercraft Development Limited. The Hythe Technical Unit of this company was recently transferred to the care of the National Physical Laboratory, another move which was met with criticism. Whatever NPL's virtues may be, they are not thought to include much 